\title{
TraduÇões Polimétricas de Plauto: EM Busca DA Polimetria Plautina EM PORTuguês
}

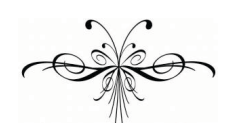 \\ Rodrigo TADEU GONÇALVES
}

Resumo: Neste artigo pretendo partir da análise de propostas já existentes de traduções polimétricas da Comédia Nova latina de Tito Mácio Plauto (sec. III-II a.C.) a fim de propor traduções desse autor que procurem o mesmo efeito em português. Os exemplos analisados serão os das traduções das comédias Amphitruo, Aulularia e Captiui por Sir Robert Allison e das comédias Asinaria e Bacchides de Edward H. Sugden para o inglês (além de uma tradução recente do autor de comédia nova grega Menandro, proposta em 2001 por Maurice Balme). Os três tradutores empregam diferentes tipos de versos, frequentemente compostos de pés jâmbicos e trocaicos, seguindo a variação polimétrica encontrada nas comédias. Minha análise procurará defender esse tipo de tradução, inédita para esse gênero em português, a fim de verificar a viabilidade de se utilizar tipos de versos similares, em uma tentativa de manter o efeito de quebras rítmicas e usos de senários jâmbicos, septenários trocaicos e de metros líricos (versos específicos da tradição greco-latina dos gêneros trágico e cômico) em traduções de teatro em português. Para tanto, serão propostos e apresentados trechos de tradução de comédias de Plauto em metros variados em português.

Palavras-chave: tradução poética, polimetria, Comédia Nova

\begin{abstract}
In this article I intend to analyse existent proposals of polymetric translation of Titus Maccius Plautus $\left(3^{\text {rd }}-\right.$ $2^{\text {nd }}$ centuries B.C.) in order to propose Portuguese translations of Plautus with the same metric effect in Portuguese. The examples we analyse are from Plautus' comedies Amphitruo, Aulularia and Captivi by Sir Robert Allison and from Asinaria and Bacchides by Edward H. Sugden (we also analyse a translation of the Greek new comedy author Menander published by Maurice Balme in 2001). The three translators employ various kinds of verses, following the trochaic and iambic polymetric variations found in the comedies. Our analysis will try to legitimate this mode of translation, not yet found in Portuguese, aiming to test the applicability of those kinds of verses to maintain the rhythmic breaks and uses of iambic senarii, trochaic septenarii and lyric verses (specific from the GreekRoman traditions of the tragic and comic genres) in dramatic translations in Portuguese. In order to do that, we present some excerpts of Plautus comedies in translation into Portuguese in different kinds of verses.
\end{abstract}

Keywords: poetic translation, polymetry, New Comedy 


\section{Métrica na Comédia}

$\mathrm{P}$ ara iniciar a discussão acerca das traduções poéticas de Plauto existentes em inglês e de nossa proposta tradutória em português, será necessário apresentar brevemente a complexidade métrica da poesia dramática da Comédia Nova de Plauto e Terêncio, que é baseada na descrição de Duckworth (1952, p. 361-383).

A Comédia Nova latina organizava a sua estrutura métrica e musical em três tipos de performances possíveis, que se alternavam em arcos recorrentes ao longo da composição dramática (cf. Marshall, 2007):

1. Passagens em senários jâmbicos (metro semelhante à conversação ordinária), chamados pelos antigos de diuerbia;

2. Passagens restantes recitativas em metros mais longos octonários jâmbicos ou septenários trocaicos, chamados de cantica;

3. Passagens provavelmente cantadas em metros variados: mutatis modis cantica: metros líricos (Plauto) ou mistura dos recitativos (Terêncio).

Os dois autores organizavam suas peças segundo padrões métricos relativamente diferentes. Alguns dados sobre a proporção de uso desses metros podem auxiliar na compreensão dos modos diferentes como Plauto e Terêncio compunham.

Os tipos de metros mais freqüentes nos dois autores eram o senário jâmbico e o septenário trocaico. No entanto, a distribuição desses tipos de versos em Plauto e Terêncio é bastante diferente: no conjunto da obra de Terêncio que chegou a nós (seis peças completas), temos cerca de 3100 senários jâmbicos e 1300 septenários trocaicos. Já nas vinte comédias quase completas e fragmentos que restaram de Plauto, temos cerca de 8800 septenários trocaicos e 8200 senários jâmbicos. Isso mostra uma preferência maior de Terêncio pelo metro mais próximo da conversação, e uma proporção mais simétrica em Plauto entre os diverbia e os recitativos mais longos. No entanto, a diferença mais radical está na proporção de uso de cantica, passagens em metros líricos e variados provavelmente cantados pelos atores. Plauto usa cerca de 3000 versos desse tipo, enquanto Terêncio, apenas 25. As conseqüências disso são um maior uso por Terêncio de versos longos acompanhados da tibia em passagens que, em Plauto, se dividem entre esse modo de recitativo e o modo cantado, o que gera, em Plauto, um maior efeito musical e de sofisticação dos tipos de versos. Essa exuberância métrica foi o motivo de nossa escolha de Plauto para analisar traduções poéticas polimétricas já existentes e propor uma tradução nossa, apenas esboçada neste artigo. 


\section{Princípios de versificação latina}

Para fins de apresentação da proposta deste artigo, parece ser razoável fazer uma apresentação breve sobre os princípios de versificação latina. Os versos gregos e latinos eram compostos através da recorrência de pés métricos compostos por sequências de sílabas longas e breves.

Uma sílaba poética é longa se:

- O núcleo da sílaba for uma vogal naturalmente longa;

- O núcleo da sílaba for um ditongo;

- O núcleo da sílaba for precedido de duas consoantes (mesmo que a segunda seja na palavra seguinte).

Nos outros casos, é breve.

Algumas características particulares importantes dos versos em Plauto e Terêncio diferenciam a produção poética desses dois autores do restante da tradição latina posterior: seus versos são quantitativos, mas com grande correspondência de ritmo e acento de intensidade; são comuns hiatos (especialmente após monossílabos enfáticos) e sinéreses (contrações de vogais separadas tornando-as uma só sílabas). Uma outra característica importante é a que foi chamada de lei da brevis brevians: uma sílaba longa precedida de uma breve pode se tornar breve se a breve anterior for acentuada ou se a posterior (breve ou longa) for acentuada. Ex: ĕgŏ ao invés de ĕgō mas não sāně ao invés de sānē.

\section{Alguns dos versos típicos da Comédia Nova}

Seguindo os princípios fundamentais esboçados acima, passemos a um catálogo de algumas das formas métricas mais comuns na Comédia Nova de Plauto e Terêncio.

\section{Senário jâmbico}

O senário jâmbico é o tipo de verso mais comum na produção dos dois autores, e corresponde ao trímetro jâmbico da tragédia e comédia gregas, verso que, segundo Aristóteles (Poética, IV), é o verso considerado o ritmo mais coloquial.

O verso se constitui de seis pés jâmbicos com substituições permitidas em todos, menos no último pé (que deve ser jâmbico ou tribráquico), com cesura normalmente após o terceiro ou quarto pé.

O senário admite a seguinte estrutura de substituições permitidas (o acento ' marca o ictus, o acento métrico do pé):

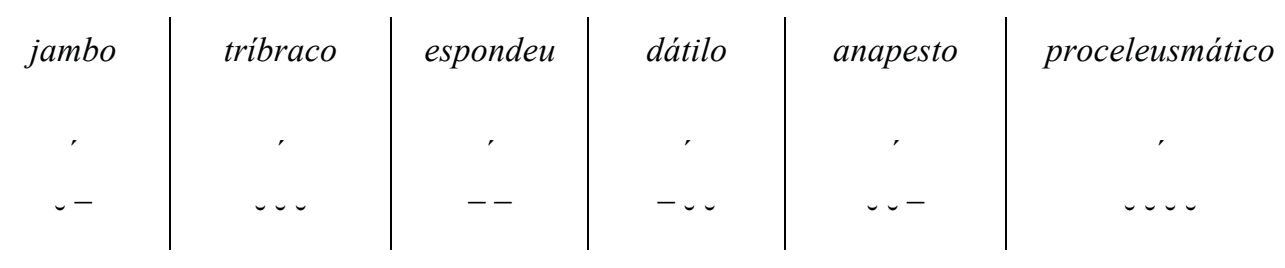


Vejamos alguns exemplos de senários jâmbicos apresentados por Duckworth (escanção minha):

$$
\text { atqu(e) hóc | poé|tae fá|ciunt }|| \text { ín | cōmoé|diís. }
$$

Men. 7

$$
\text { onerá|uit ná|uim mág|nam } \| \text { múl|tis mér|cibús. }
$$

Men. 25

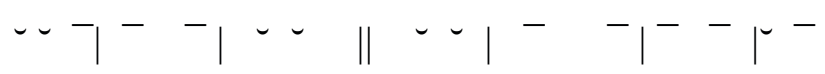

ita uí|tast hó|minum || quási | quom lú|das tés|serís.

Ad. 739

\section{Septenário trocaico}

O septenário trocaico equivale ao grego tetrâmetro trocaico. Em latim, o verso consiste de sete pés e meio trocaicos; o sétimo é sempre puro (troqueu ou tríbraco), e o fim do quarto pé geralmente coincide com uma diérese (pausa entre pés). O septenário trocaico é um dos tipos de versos mais comuns em cantica na Comédia Latina.

As substituições possíveis para o septenário trocaico são as seguintes (o acento ' marca o ictus, o acento métrico do pé):

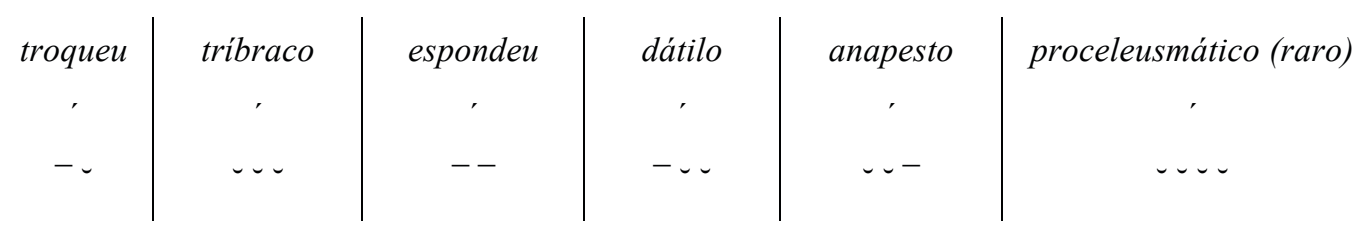

Vejamos alguns exemplos de septenários trocaicos apresentados por Duckworth (escanção minha):

néc de|márchus | néc co|márchus || néc cum | tánta | glóri|á

Curc. 286

$-\left.\right|^{-} \sim_{-} \sim^{-}-\left.\right|^{-} \|^{-} \sim^{-}-\left.\left.\right|^{-}\right|^{-}$

cúrsu | céleri | fácit(e) in|fléxa || sít pe|dúm per|níci|tás

Men. 867

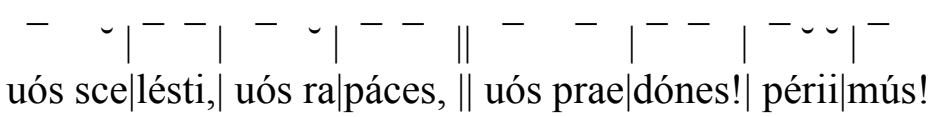

Men. 1015 


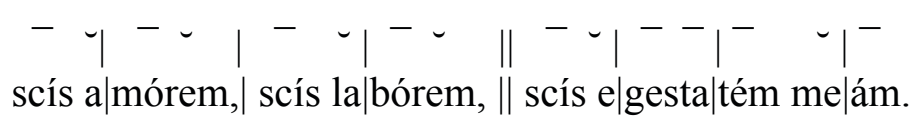

Pseud. 695

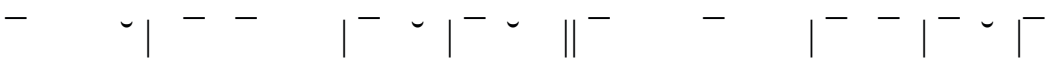

últr(o) a|más, ultr(o)| éxpe|téssis, || últr(o) ad t(e)| áccer|sí iub|és.

Asin. 526

\section{Octonários trocaicos}

O octonário trocaico consiste de oito pés trocaicos, com as substituições similares às do septenário trocaico permitidas em todos menos no último pé. Trata-se de um verso pouco frequente tanto em Plauto quanto em Terêncio. Escandimos um exemplo apresentado por Duckworth:

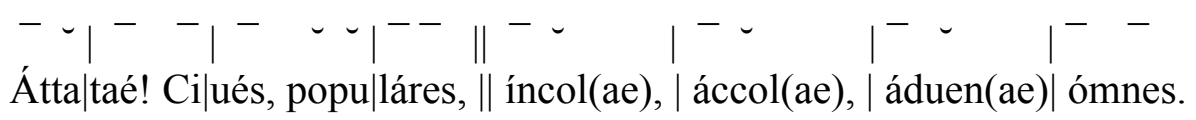

Aul. 406

\section{Septenário jâmbico}

Consiste de sete pés jâmbicos e meio, com diérese após o quarto pé. Trata-se de versos longos dos cantica que é comum tanto em Plauto quanto em Terêncio. Um exemplo escandido segue abaixo:

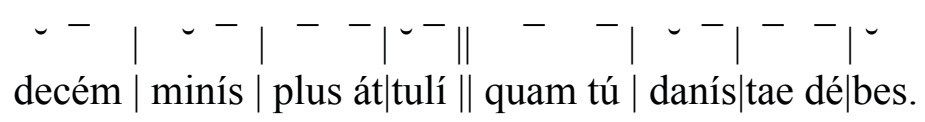

Epid. 347

\section{Octonário jâmbico}

O octonário jâmbico, composto por oito pés jâmbicos, divide-se em dois tipos básicos: com e sem diérese após o quarto pé. Terêncio preferia o segundo tipo, Plauto usava ambos. Abaixo vemos a escanção de um exemplo:

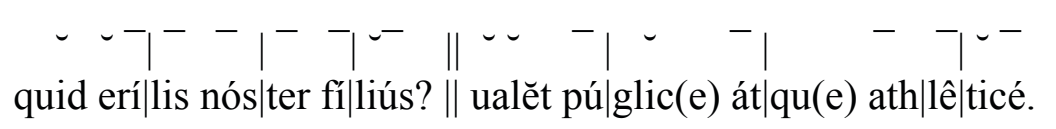

Epid. 20

\section{Mutatis modis cantica}

Em Terêncio, os cantica são basicamente compostos por metros mais longos (septenários e octonários) trocaicos ou jâmbicos (como vimos acima, contam-se apenas 25 versos líricos em três canções em toda a obra de Terêncio). Plauto, por outro lado, os combina com pés líricos baseados no anapesto ( ${ }^{-}$), 
dátilo $\left({ }^{-}\right)$, crético $\left(\left(^{-}--\right)\right.$e báquico $\left({ }^{\prime-}\right)$, em mais de sessenta canções em toda sua obra restante. Analisaremos brevemente apenas alguns dos mais comuns desses metros líricos.

\subsection{Tetrâmetros báquicos}

Os tetrâmetros báquicos consistem de quatro pés báquicos $\left(\left(^{--}\right)\right.$com um esquema de substituições complexo (peão primo ( - ), peão quarto $\left({ }^{-}\right)$, molosso $\left({ }^{-}\right)$, jônico $\left({ }^{-}\right)$e coriambo $\left({ }^{-}\right)$, entre outros cola). Tentamos escandir um trecho em tetrâmetros báquicos abaixo:

ut aétas $\mid$ meá (e)st a|tqu(e) ut hóc u|sus fácto (e)st

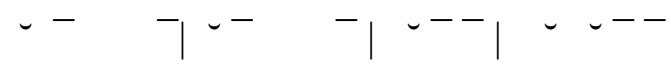

gradúm pro|ferám, pro|gredíri | properábo.

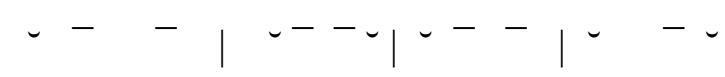

sed íd quam | mihí faci|le sít hau | sum fálsus.

Men. $753-5$

\subsection{Tetrâmetros créticos}

Os tetrâmetros créticos são basicamente iguais aos báquicos, mas com pés básicos créticos $\left({ }^{-}{ }^{-}\right.$). O esquema de substituições é igual. A diferença fundamental está no ritmo fundamental dos dois tipos de tetrâmetros. Com pés ternários repetitivos e substituições que tornavam o verso mais flexível, os báquicos e os créticos eram escolhas métricas muito comuns para cantica em Plauto, que aproveitava o efeito musical em passagens de maior conteúdo emotivo, como monólogos amorosos, desesperados, tragicômicos, entre outros. O exemplo escandido abaixo é um dos mais famosos monólogos cantados de Plauto, a passagem de paraclausithyron do Gorgulho, em que o herói canta para a porta fechada da casa da amada:

péssul(i), heus | péssuli,| uós salu|tó lubens,
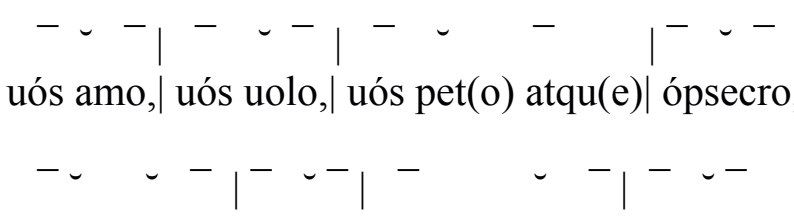

gérit(e) aman|tí mihi |mór(em), amoe|níssumi,

$--\left.\left._{-}^{-}{ }^{-}\right|^{-}{ }_{-}\right|_{-} ^{-}-$

fíte caus|sá mea |lúdii| bárbari, 
sússilit(e),| ópsecr(o), et| míttit(e) is|tánc foras

quaé mihi $\mid \operatorname{míser(o)~amant(i)|}$ ébibit $\mid$ sánguinem.

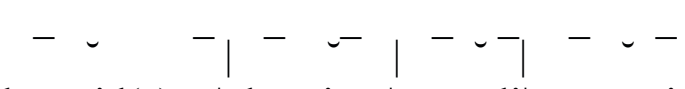

hóc uid(e) ut dórmiunt| péssuli| péssumi

néc mea| grátia| cómmouent s(e)| ócius!

Curc. $147-154$

\section{Traduções de comédia nova em versos}

Nesta seção, apresentarei algumas propostas existentes de traduções poéticas de Comédia Nova em inglês. A tradição poética do inglês privilegia os ritmos binários, uma vez que sequências rítmicas binárias são mais freqüentes em seu sistema fonológico. Assim, seu verso mais comum é o pentâmetro jâmbico (seu equivalente mais próximo do nosso decassílabo), o que facilita a reprodução poética dos versos básicos jâmbicos da Comédia Nova (lembremo-nos da associação de Aristóteles entre o trímetro jâmbico grego, equivalente do senário jâmbico latino, à conversação ordinária). Assim, encontraremos como verso básico da tradução de comédia antiga em inglês o verso mais canônico de sua tradição poética (verso utilizado no teatro Shakespeariano, por exemplo). No entanto, partindo desse padrão métrico, os tradutores poéticos que tentaram emular a polimetria dos dramaturgos antigos muitas vezes variavam entre ritmos jâmbicos e ritmos trocaicos, utilizando-se, como veremos em alguns casos, inclusive, de estruturas poéticas líricas equivalentes em passagens de cantica.

Comecemos por analisar a tradução da obra completa de Menandro por Maurice Balme (Balme, 2001), feita a partir do metro básico jâmbico inglês. O exemplo reproduzido aqui é o de uma passagem da comédia Samia, em que, na ocasião da troca de atos, seguindo a estrutura métrica de Menandro (trímetro jâmbico na primeira parte e tetrâmetros trocaicos na segunda), Balme varia a estrutura métrica da tradução, do pentâmetro jâmbico para uma espécie de septenário trocaico inglês a partir do verso 421 (sete pés trocaicos invariáveis):

Nikeratos. He must be sick.

The Black Sea's not at all a healthy place.

Come with me to my wife. Cheer up! Don't fret!

He'll cease this madness soon when he reflects

And gives some thought to what he's doing now.

[Exit nikeratos into his house together with chrsyis., the baby, the nurse, and the sheep]

ACT4

Enter nikeratos from his house, speaking over his shoulder to his wife. nikeratos. Wife, you'll wear me all to pieces. I'm off now to tackle him.* [He soliloquizes] I would not have had this happen if you'd offered me a fortune, Heavens, no, I really wouldn't. When the wedding's Just begun, Here's a most untimely omen come on us; a girl's arrived At our house, thrown out by someone, with a baby in her arms. 
So there're tears and all the women have completely gone to pieces.

Demeas has proved a shit and, god, I'll make him pay for this.

Passemos a traduções poéticas de Plauto para o inglês. Os dois tradutores apresentados, Sir Robert Allison e Edward Sudgen, são alguns dos tradutores presentes na edição de todas as peças do teatro romano feita por Duckworth (1942). De todos os tradutores, apenas os dois analisados aqui apresentaram traduções poéticas, e discutimos alguns trechos representativos de suas traduções.

Iniciamos com um trecho do Anfitrião na tradução de Sir Robert Allison em pentâmetros jâmbicos tradicionais, em uma passagem de monólogo do escravo Sósia:

Act One. Scene I (Enter Sosia from the harbour, holding a lantern.)

Sosia (to himself): Is there a bolder or more valiant man

Than I, who know the habits of our youth,

Yet walk abroad by night and all alone?

And what if the night-watchmen in their rounds

Put me in jail, and from the prison's cell

Tomorrow I was handed over to

The whipping-post, no one to take my part,

And no help from my master; none to think

Me worthy; eight strong fellows then would flay

My back as 'twere an anvil; such would be

The public welcome that I should receive,

On thus returning from a foreign shore.

A próxima passagem, da mesma peça, é de um monólogo cantado por Mercúrio, em que temos uma estrutura métrica lírica com versos constituídos basicamente por dois hemistíquios com um coriambo $\left(-{ }^{-}\right.$) cada. Em alguns hemistíquios, antes do coriambo, temos um anapesto (como nos versos 986 e 987), exercendo uma função próxima de uma anacruse, que em alguns outros versos, como no 988, se realiza apenas como uma sílaba breve antes do coriambo. Nesta passagem temos, claramente, a emulação de um trecho de canticum, em que as substituições e a flexibilização do dímetro coriâmbico tentam dar maior flexibilidade aos versos:

Act Three. Scene IV

Mercury (to imaginary passers-by): Out of the way, out of the way, 983 all you good people, out of the way!

He's a bold man who'd venture to stay

When I bid him to go; I'm a god, and can threaten

The people as much as a slave who is beaten,

In comedies often; they come in and tell

That the ship has arrived in port safe and well;

Or some angry old gentleman is come on the scene.

I am the servant of Jove, and so long have been;

I obey his behests, so why shouldn't I make

All you people depart to make room for my sake.

The father, he summons, I come at his call,

As good son should do, I obey him in all;

I flatter and fawn, assist, humour his whim,

Give advice and joy with him; what's pleasant to him

Is always the greatest of pleasures to me. 
A passage seguinte é da peça Aululária ainda na tradução de Sir Robert Allison, que representa o esquema métrico mais frequente em suas traduções poéticas de Plauto, emulando, assim, a alta frequência de uso do senário jâmbico, facilitado pela tradição métrica inglesa:

Act Four. Scene IX

(Enter Euclio frantic.)

Euclio (to himself): I'm ruined, slaughtered, quite undone! Oh, where 713

Am I to go? Or not to go? Stay! Stop!

But whom? Or what? I cannot see, I'm blind!

I cannot say for certain where I go,

Nor where, nor who I am. (To audience) I pray your help

To point me out the man who stole the gold.

Ay, there they sit in white like honest men.

What say you? I can trust you; and I know

An honest man by sight. What is it now?

Why do you laugh? There are thieves enough, I know,

And many thieves. What, none of these have it?

You kill me! Don't you know? Say who it is.

Alas, alas, I am undone! I'm killed!

A pretty state of things! So much of woe,

So much of grief has this day brought to me!

Hunger and poverty, most wretched man!

What hope of life to one who's lost so much,

So much that I have guarded? I denied

Myself all pleasure; others now will joy,

At my expense, my loss. I cannot bear it!

Transcrevemos um último exemplo de pentâmetros jâmbicos, do mesmo tradutor, agora da peça Cativos. Um exemplo de problema encontrado pelo tradutor na manutenção do ritmo básico jâmbico é visível nos versos 463 e 465, em que o polissílabo miserable altera sutilmente o ritmo jâmbico, produzindo algum grau de flexibilização, mais difícil de conseguir em inglês do que em latim, pelas possibilidades de substituições do senário, discutidas acima:

Act Three. Scene I

(Enter Ergasilus from the forum.)

Ergasilus (to himself): A miserable lot is his, who has

To seek a dinner, and can scarcely find it.

More miserable still is his by far

Who seeks and nothing finds; and yet again

Most miserable is he of all who wants

To eat and nothing has. For, by the gods,

I'd drag the eyes out of this wretched day;

All mortals has it turned against me with

Undying hate! A day more hungerful,

More with starvation crammed, I never saw,

Nor one in which what one begins to do

Has less success; a day on which my throat

And stomach celebrate a famine fast.

The parasite's profession's dead and gone! 
$\mathrm{Na}$ sequência, analisamos alguns trechos de tradução de Edward Sudgen, iniciando pela Asinária, de Plauto. Aqui, temos um trecho em pentâmetros jâmbicos com algum grau de flexibilização, especialmente no verso 119 e 125, em que o ritmo básico jâmbico é alternado em alguns pés com anapestos ("or more DIFficult to DODge"), ou ainda com versos fundamentalmente trocaicos, como "BUT I'll BE off TO the MARket, AS I PURposed".

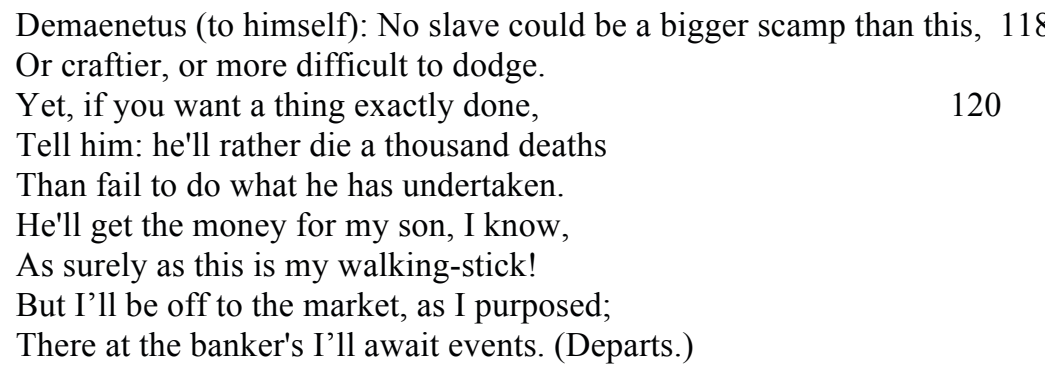

$\mathrm{Na}$ quebra de ato, temos, como de costume nas peças latinas, alteração no esquema métrico. No monólogo de entrada de Argíripo, inicialmente temos versos rimados com a estrutura de três dátilos seguidos de um troqueu ou um dátilo dos versos 127 a 136, quando, no meio do monólogo, o tradutor alterna os tetrâmetros datílicos para uma sequência de octonários trocaicos, versos que emulam os versos longos dos cantica recitativos de Plauto. $\mathrm{O}$ esquema de rimas parece ser um recurso pouco trabalhado pelo tradutor, pois há rimas AABBCCEEEE, seguidas de AABBCCDDEEFFGGG, e muitas vezes a rima é pobre, com a mesma palavra sendo usada no final de alguns dos dísticos:

Act One. Scene II

(Enter Argyrippus hastily from the house of Cleareta.)

Argyrippus (angrily, to those within): Oh, has it come to this? Kicked out of doors by her!

This is the prize for my gifts that she stores by her!

Foe to your friend, and a friend to your foe, you are.

Curse you! I'll soon let the magistrates know you are

Swindler and thief, of young fellows the slaughterer!

Oh, I'll bring ruin on you and your daughter there!

Sea's no more sea when compared with your treachery!

There I got gain, which I lost by your witchery.

All my kind gifts I've bestowed so effusively

Only provoke you to treat me abusively.

Now, I'll do you all the mischief in my power, and serve you right!

Back to poverty I'll drive you, out of decent people's sight.

Yes, by Jove, I'll make you know, ma'am, what you are, and what you were

In the days before I came and gave my loving heart to her.

140

Dry bread was a dainty to you in your rags and poverty;

If you got e'en that, you blessed the gods above on bended knee.

Now, you wretch, when things are better, you forget who gave good cheer.

Ah, you savage beast! With hunger will I tame you. Never fear!

I've no reason to be angry with the girl; she's not to blame;

She's compelled to do your bidding, tyrant with a mother's name!

You I'll be revenged on! You to utter ruin I'll send!

Ah! The wretch! Why, don't you see, she doesn't even condescend

Now to come and talk with me, my grace and pardon to implore! 
There! Behold, the witch is coming! Here at last, outside the door, 150 I shall speak my mind. I couldn't there, inside the house, before.

Finalmente, alguns trechos da tradução das Báquides de Edward Sudgen, os mesmos que apresentaremos em tradução para o português na próxima seção. Iniciamos com um monólogo recitativo de Mnesíloco traduzido em octonários trocaicos:

\author{
Act Three. Scene II \\ Mnesilochus (to himself): After much consideration, hither my conclusions \\ tend; \\ Nothing, save the gods, is better than a tried and trusty friend, \\ One I mean who really is so; and I'll tell you how I know: \\ When I'd gone to Ephesus, which happened some two years ago, \\ To my comrade, Pistoclerus, I despatched a messenger, \\ Begging him to find my sweetheart, Bacchis; now with joy I hear \\ He has found her, so my servant Chrysalus brings word to me. \\ Then against my worthy father he's devised some trickery, \\ To procure me all the money I require. [Why, there's my friend!]
}

A passagem seguinte, também um monólogo de Mnesíloco, é traduzida no tradicional pentâmetro jâmbico:

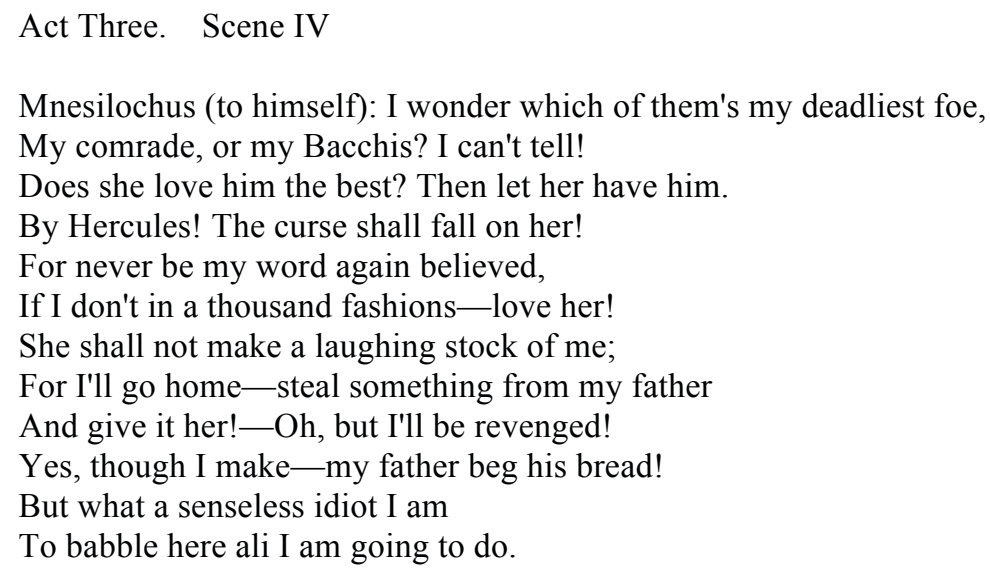

Tendo apresentado os dois modelos básicos de passagem falada em pentâmetros jâmbicos e recitativo em octonário trocaico, a seguir podemos ver uma passagem de canticum lírico traduzido por Sudgen em tetrâmetros jâmbicos ágeis, rimados inicialmente em dísticos, e, a partir do verso 939, em quadras com rimas do tipo ABBA. Trata-se de uma passagem de canticum lírico no texto plautino, e a solução de Sudgen parece se utilizar de uma estratégia tradutória de compensação, já que a polimetria foi eliminada no trecho, ao propor, no lugar da variação rítmica radical, rimas e estrofes (inexistentes na tradição poética da Comédia Latina) em versos curtos de mesma estrutura rítmica, mais adaptados para passagens líricas na tradição poética inglesa: 
Act Four. Scene IX (Enter Chrysalus from the house of Bacchis, with a letter in his hand.)

Chrysalus (to himself): The sons of Atreus gained great fame,

When Priam's town they overcame,

And levelled the proud walls of Troy,

Whose building was the god's employ;

With foot and horse, an army stout,

And warriors famed the world about,

And a good thousand ships to boot,

It took them ten full years to do't.

But Priam knew no such disaster

As I've inflicted on my master.

Without a fleet, without an army,

Or host of soldiers to alarm ye,

His father's gold I've stormed and won

To give it to his love-sick son.

Before he comes, my feelings urge

That I should sing the old man's dirge:-

O Troy, my home! O Pergamum!

O Priam old! Alack the day!

Thou hast a fearful fine to pay!

Four hundred Philips is the sum.

This letter, which I here present,

All signed and sealed in proper course,

Is not a letter, but a horse,

The horse of wood the Grecians sent.

Our Epius is Pistoclerus;

I've left Mnesilochus, our Sinon,

No hero's barrow to recline on.

But in the house of Bacchis near us.

Bacchis, who's with him, is the fire For flashing signals; but her kisses

Burn him instead! I am Ulysses,

Who formed the plan at their desire.

The letters written hereupon

Are soldiers hidden in the horse,

All clad in arms and full of force;

So far the thing goes bravely on.

Not his stronghold but his strong-box

Shall feel my horse's bold attack;

Destruction, death, damnation black,

Shall seize his gold in spite of locks.

\section{Propostas de traduções para o português}

Nesta seção, apresento brevemente algumas tentativas iniciais de verter a polimetria plautina para metros não muito convencionais em português. As 
tentativas tentam superar problemas fundamentais de adequação dos metros binários básicos de Plauto à tradição poética portuguesa, propondo metros jâmbicos ou trocaicos com algum grau de flexibilização métrica, como veremos abaixo.

O primeiro trecho apresentado abaixo, originalmente escrito em septenários trocaicos (apresentada também na tradução de Edward Sudgen, acima, em octonários trocaicos), resultou em uma tradução poética relativamente fluente em português. Ao invés de propor versos com o mesmo número de pés trocaicos, a flexibilização foi buscada através de números variáveis de troqueus. A única passagem em que não foi possível manter o ritmo trocaico substituiu um dos pés por uma sequência espondaica, em "dois anos":

Mnesíloco:
Tendo eu pensado aqui comigo em muitos jeitos, acho assim:
nada - fora os deuses - ultrapassa o amigo, quando ele
tem assim o nome em alta conta. Sei que é assim por obras.
Quando fui pra Éfeso daqui - aconteceu há quase dois anos -
lá de Éfeso ao amigo Pistoclero eu mandei uma carta
pra que ele achasse a minha amante, a Báquis. Acho que ele
encontrou; e foi o que me disse o meu escravo Crísalo.
Esse então, quão apropriadamente fez um plano
contra o pai, pra que eu tivesse grana pro amor. Tem gente vindo.

\{MNESILOCHVS $\}$ Múltimodis meditatus egomet mecum sum, et ita esse arbitror:

homini amico, qui est amicus ita uti nomen possidet, nisi deos ei nil praestare; id opera expertus sum esse ita. nám ut in Ephesum hinc abii (hoc factumst ferme abhinc biennium) ex Epheso huc ad Pistoclerum meum sodalem litteras misi, amicam ut mi inveniret Bacchidem. illum intellego invenisse, ut servos meus mi nuntiavit Chrysalus. condigne is quam techinam de auro advorsum meum fecit patrem, ut mi amanti copia esset. [séd eccum video incedere.]

Uma segunda passagem, de original em senários jâmbicos, foi proposta através da emulação em versos de seis pés jâmbicos em português. A passagem apresenta algumas inversões de ordem sintática típicas do latim e pouco comuns em português, como em "se a não de muitas formas, claramente - amo", tanto para apresentar algum grau de estranhamento na tradução, quanto para manter o efeito de para prosdokian, uma quebra de expectativa poética para fins cômicos. Além disso, a tradução tentou manter um equilíbrio entre a forma métrica estrangeirizante proposta para o português e o tom cômico coloquial. O trecho também foi apresentado acima em senários jâmbicos na tradução de Edward Sudgen. Vejamos o texto:

\footnotetext{
Mnesíloco:

Não sei quem é mais inimigo agora - muito incerto - se a Báquis ou o meu amigo.

A ele ela prefere? Ótimo, que fique.

Nem isso fez, por deus, sem grande mal pra si.

Pois nunca creiam mais em mim nenhum dos deuses,

Se a não de muitas formas, claramente - amo.

Farei com que não diga que encontrou alguém

de quem se riu; já vou pra casa e roubarei
} 
alguma coisa de meu pai pra dar pra ela. De muitos modos eu me vingarei da tal. Vou coagi-la até que venha mendigar meu pai. Será que estou bom da cabeça aqui falando do futuro assim aqui sozinho?

\{MNES.\} Inimiciorem nunc utrum credam magis sodalemne esse an Bacchidem, incertum admodumst. illum exoptavit potius? habeat. optumest. ne illa illud hercle cum malo fecit suo; nam mihi divini numquam quisquam creduat, ni ego illam exemplis plurumis planeque - amo. ego faxo hau dicet nactam quem derideat. nam iam domum ibo atque - aliquid surrupiam patri. id istí dabo. ego istanc multis ulciscar modis. adeo égo illam cogam usque ut mendicet - meus pater. sed satine ego animum mente sincera gero, qui ad hunc modum haec hic quae futura fabulor?

O último trecho, traduzido em tetrâmetros jâmbicos rimados e em estrofes por Sudgen, apresentado na seção anterior, foi traduzido para o português aqui em versos mais longos fundamentalmente jâmbicos, que variam de sete a nove pés, porém com maior flexibilização dos pés, através de tentativas de substituição dos jambos tradicionais por anapestos, quando necessário. Assim, esse parece ser um dos trechos mais ousados da proposta, uma vez que deve ser reconhecido como um tipo de prosa rítmica de batidas fundamentalmente jâmbicas. No sistema poético português, esses versos não poderiam ser classificados como pertencentes à tradição poética. No entanto, a flexibilização do ritmo jâmbico em versos longos parece ser uma saída interessante para os trechos de cantica numa proposta polimétrica em português. Vejamos o trecho:

Os dois Atridas, dizem alguns, a audácia máxima perpetraram quando a pátria de Príamo velho, Pérgamo por mão de deus munida, com exército, armas, cavalos e muitos homens exímios para a guerra, após o décimo ano, tendo mil navios, subjugaram.

Não foi nem mesmo uma bolha no pé comparada ao modo pelo qual ao meu senhor eu hoje engano, sem exército nem frota nem número tal de homens - eu limpei o velho em favor do filho. e agora, antes que venha aqui o velho, devo compor um lamento. Ó Tróia, ó pátria, ó Pérgamo, ó Príamo velho, vós sois não mais do que os quatrocentos dobrões do rei Felipe ao velho subtraídos.

\{CHRYSALVS $\}$ Atridae duo fratres cluent fecisse facinus maxumum, 925 quom Priami patriam Pergamum divina moenitum manu armis, equis, exercitu atque eximiis bellatoribus mille cum numero navium decumo anno post subegerunt. non pedibus termento fuit praeut ego erum expugnabo meum sine classe sineque exercitu et tanto numero militum. 930 [cepi expugnavi amanti erili filio aurum ab suo patre.] nunc prius quam huc senex venit, libet lamentari dum exeat. o Troia, o patria, o Pergamum, o Priame periisti senex, qui misere male mulcabere quadringentis Philippis aureis. 


\title{
Considerações finais
}

O presente artigo pretendeu apresentar traduções poéticas já existentes de peças da Comédia Nova grega e latina que levassem em consideração a polimetria presente na construção poética desses gêneros, a fim de verificar, através de algumas tentativas iniciais, a viabilidade da emulação dessa característica no sistema poético português. A partir da análise das possibilidades poéticas da Comédia Nova, buscamos, na última parte, formas poéticas que mantivessem algum grau de variabilidade rítmica a fim de recriar, em um sistema poético de contagem de sílabas como o português, as possibilidades fundamentalmente rítmicas especificamente da poesia plautina. $\mathrm{O}$ artigo apresenta pouca articulação teórica, mostrando-se bem mais prático nas análises críticas das traduções existentes em uma tradição que aceita melhor os versos constituídos de unidades rítmicas, como a inglesa e nas propostas de emulação dessa característica no sistema poético português. Assim, o que se busca, na verdade, é a sustentação crítica e prática para propostas de tradução poética polimétrica de peças inteiras de Plauto e Terêncio em português, quase sempre traduzidas em prosa ${ }^{1}$, o que, na nossa opinião, deixa de lado uma dimensão da poesia dramática antiga essencial para o todo poético dos autores.

\author{
Rodrigo Tadeu Gonçalves \\ goncalvesrt@gmail.com \\ Universidade Federal do Paraná
}

\section{Referências bibliográficas}

Aristóteles; Horácio; Longino. A poética Clássica. Trad. de Jaime Bruna. São Paulo: Cultrix, 1997.

BEARE, William. The Roman Stage: a short history of Latin drama in the time of the republic. London: Methuen \& Co. Ltd., 1964.

CArdoso, Isabella Tardin. Estico de Plauto. Edição Bilingüe. Campinas: Editora da Unicamp, 2006.

ChOciay, Rogério. Teoria do Verso. São Paulo: McGraw-Hill do Brasil, 1974.

ConTe, Gian Biagio. The Rhetoric of Imitation. Ithaca: Cornell University Press, 1996.

\footnotetext{
${ }^{1}$ A única exceção que conhecemos, de tradução poética de comédia nova latina em português em versos, é a tradução em decassílabos de quatro comédias de Terêncio proposta por Leonel da Costa Lusitano (Terêncio, 1945). No entanto, muito boas traduções poéticas, e até mesmo polimétricas, de tragédias gregas, são comuns no Brasil, cf. a tradução do Filoctetes de Sófocles em metros variados por Trajano Vieira (Sófocles, 2009).
} 
CRUsius, Federico. Iniciación en la Métrica Latina. Versão e adaptação de Ángeles Roda. Barcelona: Bosch Casa Editorial, 1951.

Duckworth, George E. (Ed.) The Complete Roman Drama in Two Volumes. New York: Random House, 1942.

- The Nature of Roman Comedy. A Study in Popular Entertainment. New Jarsey: Princeton University Press, 1971.

Fujihara, Álvaro Kasuaki. Aspectos tradutórios em Terêncio. Monografia de conclusão de curso. UFPR, 2006, inédita.

GonçAlves, R. T. Comédia Latina: a tradução como reescrita do gênero. Revista PhaoS, 9, Unicamp, 2009. p. 117-142.

Handley, E. W. Menander and Plautus - a Study in Comparison. London: HK Lewis, 1958.

Hunter, R. L. The New Comedy of Greece and Rome. Cambridge: University Press, 1985. Blackwell Companions to the Ancient World.

LEFEVERE, André. Tradução, reescrita e manipulação da fama literária. Trad. Claudia Matos Seligmann. Bauru: Edusc, 2007.

LeIGH, M. Comedy and the Rise of Rome. Oxford: University Press, 2004.

Marshall, C. W. The Stagecraft and Performance of Roman Comedy. Cambridge: University Press, 2006.

MenANDER. The Plays and Fragments. Oxford's World Classics. Trad. Maurice Balme. Oxford: University Press: 2001.

MENANDRO. Obra Completa. Introdução, tradução do grego e notas de Maria de Fátima Sousa e Silva. Faculdade de Letras da Universidade de Lisboa: Imprensa Nacional-Casa da Moeda, 2007.

Plautus, T. Maccius. Bacchides (Plauti Comoediae. Vol. 1, ed. F. Leo, 1895), edição do software Diógenes.

Plautus. T. M. Plauti Comoediae (Oxford Classical Texts). Oxford, Clarendon Press, 1904. 2 volumes. Ed. W. M. Lindsay.

Plavtvs. Bacchides. Nota introdutiva e testo critico di Cesare Questa. Firenze: Sansoni Editori: Firenze, 1975.

Segal, Erich (ed.) Oxford Readings in Menander, Plautus and Terence. Oxford: University Press, 2001.

- Roman Laughter - The Comedy of Plautus. Oxford: University Press, 1987.

SóFOCLES. Filoctetes. Edição bilíngüe. Tradução, posfácio e notas de Trajano Vieira. Ensaio de Edmund Wilson. São Paulo: Editora 34, 2009.

Terêncio. Comédias: Andria, Eunuco, Heautontimorumenon, Adelfos. Tradução clássica portuguesa de Leonel da Costa Lusitano. São Paulo: Edições Cultura, 1945.

Terentius, Comoediae (Oxford Classical Texts). 2nd edition. Ed. R. Kauer et W.M. Lindsay. Oxford, Clarendon Press, 1926. 